\title{
EISNER v. MACOMBER AND SOME INCOME TAX PROBLEMS
}

\author{
Charles E. Clark \\ Assistant Professor of Law, Yale University
}

The long awaited decision of the United States Supreme Court in Eisner v. Macomber (I920) 40 Sup. Ct. I89, ${ }^{1}$ has aroused perhaps more interest than is merited by the actual decision, which is simply that dividends of a corporation declared by issuing its own stock are not income within the meaning of the Sixteenth Amendment. The flurry in the stock market caused by the erroneous report of the decision, ${ }^{2}$ the way in which the Court divided, ${ }^{3}$ and the criticism of the decision in Congress and elsewhere, coupled with the view that the Government must necessarily lose much revenue, have added to the general interest elicited by the case.

While the decision does suggest interesting questions for the future, it was scarcely unexpected. Before the passage of the Sixteenth Amendment the Court had held that as between lifetenant and remainderman stock dividends were not income but capital going to the remainderman." And under the I9I3 income tax act the Court in Towne v. Eisner, ${ }^{5}$ in holding that the act did not contemplate the taxing of stock dividends, had stated that such a dividend

\footnotetext{
${ }^{2}$ For complete statement of facts, see infra, CuRrent Decisions. The case was argued in April, I9I9, reargument was called for in May。 I9I9, and the case was reargued in October, I919. There is now pending in Congress H. R. 13074, imposing an excise tax upon corporations of fifteen per cent. of the face value of shares of stock issued as a stock dividend.

2See (1920) 29 Yale Law Joưrnal, 678.

${ }^{3}$ Dissenting opinions were filed by Justice Holmes (Justice Day concurring) and Justice Brandeis (Justice Clarke concurring). It seems almost settled practice for the Supreme Court to hold acts unconstitutional by only a majority of one.

'Gibbons v. Mahon (1890) I36 U. S. 549, Io Sup. Ct. 1057. This is the so-called Massachusetts rule. Minot v. Paine (1868) 99 Mass. IaI; Smith v. Dana (1905) 77 Conn. 543, 60 Atl. Ir7. Under the somewhat similar English rule regular or ordinary dividends go to the life tenant while extraordinary dividends go to the remainderman. Brander v. Brander (1799, Eng. Ch.) 4 Ves. 800; cf. Bouch v. Sproule (1887) L. R. I2 App. Cas. 385. Under the Pennsylvania rule a stock dividend is apportioned between the life tenant and remainderman according to the time of accumulation of the-fund from which the dividend is declared with reference to the time of the creation of the trust. Earp's Appeal (1857) $28 \mathrm{~Pa}$. 368; Matter of Osborne (1913) $209 \mathrm{~N}$. Y. 450, I03 N. E. 723. See (I9I6) 29 Harv. L. Rev. 55I; (1919) I8 MICH. L. Rev. 69. That a stock dividend, unlike a cash dividend, may be revoked after its declaration, see_(Ig17) 26 Yale LaW JourNal, 598.

${ }^{5}$ (19I8) 245 U. S. 4I8, 38 Sup. Ct. 158. See Conment (1918) 27 Yale Law Jotrnal, 553.
} 
was properly capital. ${ }^{6}$ The present case arose under the IgI6 act, which, like the later income tax acts, expressly attempted to treat such dividends as income. ${ }^{7}$ Justice Pitney, speaking for the majority, reiterates the previous view of the Court that such dividends are in effect only a book adjustment of the corporation, being a transfer of surplus to capital stock, and that the proportionate interest of the stockholder has in no manner been changed by the declaration of the dividend. ${ }^{8}$ Especially telling is his argument that by such declaration the taxpayer receives no income from which to pay an income $\operatorname{tax}$ and, if without other assets, must sell some of his shares to make payment. By such sale his proportionate interest in the corporate assets would be lessened and his capital impaired. Therefore the Court considered that the act was unconstitutional under the Sixteenth Amendment which gives Congress the power to lay and collect taxes on "incomes from whatever source derived" without the apportionment according to population required of direct taxes under the original provisions of the Constitution. ${ }^{9}$

As Justice Holmes wrote the opinion in Towne v. Eisner, his dissenting opinion, concurred in by Justice Day, is of especial interest. He adheres to his view that on sound principles a stock dividend is not income, but believes that the term "income" in the Amendment is broad enough to include stock dividends, since the purpose of the Amendment "was to get rid of nice questions as to what might be direct taxes" and that most people not lawyers would suppose that in voting for the Amendment they had put questions like the present to rest. And he refers to the Massachusetts ruling where such a

'In Peabody v. Eisner (ror8) 247 U. S. 347,38 Sup. Ct. 546, dividends paid in the stock of another corporation were held taxable. Dividends payable out of surplus acquired before the passage of the Sixteenth Amendment may be taxed if declared thereafter. Lynch v. Hornby (I9I8) 247 U. S. 339, 38 Sup. Ct. 543. But not where the later transaction is mere bookkeeping rather than the declaration and payment of dividends in ordinary course. Southern Pacific Co. v. Lowe (rgr8) 247 U. S. 330, 38 Sup. Ct. 540; Gulf Oil Corporation v. Lewellyn (1918) 248 U. S. 7x, 39 Sup. Ct. 35; see also note 22, infra.

'Rev. Act. of Sept.' 8, 1916, ch. 463, sec. 2 a, 39 Stat. L. 756, 757; ibia., Oct. 3, 1917, ch. 63, sec. I211, 40 Stat. L.; ibid., Feb. 24, 19r9, ch. I8, sec. 20 I a, c, d, 40 Stat. L. I059 (Act of I9I8).

${ }^{8}$ Compare authorities cited in note 4, supra. There is only "a mere shuffling of titles." Davenport (Igr8) 4 Bulletin National Tax Ass's, 53. Seo discussion of Professor F. R. Fairchild and Mr. Bond in (1918) 3 ibid., 161-163, 237-243, also complete discussion by Professor Seligman, Are Stock Dividents Income? (IgI9) 9 AM. EcoN. Rev. 5I7. In Montgomery, Income Tax Procedure (1918) 188, a comparison is suggested of the change of a five dollar bill into five one dollar bills.

-The two constitutional restrictions on the power of Congress to levy direct taxes are found in Art. I, sec. 2, par. 3, modified by the Fourteenth Amendment, and Art. I, sec. 9, par. 5, of the federal Constitution. 
view was taken of a state income tax amendment. ${ }^{10}$ The view of "most people," however, must necessarily be a controversial matter and inasmuch as reason and the decision of the Court previous to the Amendment are contrary to this suggested view, it is quite as justifiable to believe that most people felt otherwise. And unfortunately the Amendment did not take the desirable course of settling all questions as to direct taxes by removing all direct tax restrictions from the Constitution, but definitely left such requirements effective except as to direct taxes on incomes. ${ }^{11}$

Justice Holmes' view does, however, point the way to dangers that may arise from a too narrow construction of the Amendment. Economists are not agreed as to the meaning of the term "income"12 and surely the Supreme Court cannot expect to decide for itself each minor provision of an income tax as to inclusion or deduction in computing taxable income. Its bias in construing a statute is to construe it strictly, but in construing a constitutional provision its bias must be to favor the judgment of the law-making body as far as possible, i. e., to uphold the constitutionality of the statute. ${ }^{13}$ Hence while the decision in Eisner $v$. Macomber seems quite simply correct, if it is to be pressed to the extent of unduly hampering Congress its results will be unfortunate.

Justice Brandeis' positiots, concurred in by Justice Clarke, is essentially the same as that of Justice Holmes, though he makes a more elaborate argument that stock dividends may properly be considered income. His most striking point is that in corporate financing there is no real difference between a stock dividend and a cash dividend coupled with the privilege of subscribing to an additional issue of stock, the subscription to be paid by the cash dividend. Either seems to be considered by financiers as a stock dividend. In the latter case the dividend is admittedly taxable. But the difference, nevertheless, is real. It is the difference between realized and unrealized investment or capital gains. The fact that the choice of methods is with

\footnotetext{
${ }^{10}$ Tax Com'r v. Putnam (1917) 227 Mass. 522, II6 N. E. 904, L. R. A. I9I7 F 806, construing the 44th amendment to the constitution of Massachusetts. See also Wilder v. Trefry, Com'r (1920, Mass.) I25 N. E. 689, holding that accrued cumulative dividends on preferred stock are taxable as income. In Great Britain, where there is no constitutional restriction, stock dividends have been held taxable under an act of West Australia. Swan Brewery Co., Ltd. v. The King [1914] A. C. 23I.

${ }^{12}$ Cf. (March 20, 1920) 2 The REvIEw, 271. An amendment removing all constitutional restrictions as to direct taxes has been vigorously urged. Seligman, The Income Tax (2d ed. 1914) 594; Whitney, The Income Tax and the Constitution (Igo7) 20 HaRv. L. Rev. 280, 296.

${ }^{12}$ See, e. g., the laws of different countries collected in Seligman, op. cit., as well as the views of economists cited throughout this article.

${ }^{13}$ Authorities cited by Justice Brandeis, dissenting; see also Tax Com'r $v$. Putnam, supra; (IgI8) 27 YAle LAW JoURAal, 553, 555.
} 
the corporation does not change this situation. One may own real estate under conditions where there is little doubt that its value has appreciated and yet that appreciation is too indefinite to be considered income or even "profits" until it is definitely ascertained as it may be when the owner decides to and does sell. This seems to be the real difference between the case put by Justice Brandeis and the situation presented in Eisner v. Macomber. In one the measuring stick for appreciation, i. e., realization, has been applied, in the other it has not. And if, as hereinafter discussed, realized capital gains are taxable, the fears of Justice Brandeis and of Congressmen as to the great loss of revenue to the government are largely groundless. ${ }^{14}$

Now it would seem clear that mere general appreciation in value of capital should not be deemed income so long as it is unrealized to the owner, ${ }^{15}$ and this is the distinction attempted to be made by the government under the present income tax law which purports to tax profits from the sale of capital items. ${ }^{18}$ It may not always be a simple matter to decide just what constitutes a realization of income; but the goal is fairly clear. Is such realized gain fairly to be considered as income within the meaning of the Amendment? It is submitted that the answer should be in the affirmative ${ }^{17}$ and this is clearly the

14 The result in the main is simply to defer the time when the stock may be taxed. A change in the rate of tax from year to year may of course make a difference in receipts from the tax, and so may the practice referred to hereinafter of taking investment losses and reinvesting in tax exempt securities. On the other hand the government may gain under the existing system of graduated taxes. Thus under the present law, note 7 , supra, the stock dividend was to have been valued to the amount of the earnings or profits distributed i. e., usually at par. U. S. Int. Rev. Regulations 45 (I9I9) art. 1545. Suppose a stock dividend is declared this year and sold at twice its. par value next year. If the stock dividend was taxed as income this year and the increase in value realized on sale was taxed next year, the total tax is spread over two years. If only the profit from the sale is taxable, the entire value will be taxed next year and thus possibly bring up the tax payer's total income, so that a higher surtax rate applies. $C f$. note 30 , infra.

${ }^{15}$ Seligman, Are Stock Dividends Income? op. cit., 517, 536: "The real distinction to be kept continually. in mind in threading one's way through the mazes of the income tax is between the actual receipt of income on the one hand and the unrealized appreciation of capital on the other." Quoted with approval in Montgomery, Income Tax Procedure (1920) 483. See also Seligman, ibid., 530. "Separation and realization are of the essence of the transmutation of capital into income."

${ }^{16}$ Act, Feb. 24, 1919, secs. 202 a, 213 a; Art. 1563 of Regulations 45 supra. (Cf. Treasury Decision 297I, Feb. 4, I920) "Both a change in substance and not merely in form, and a change into the equivalent of cash are required to complete or close a transaction from which income must be realized." Montgomery, op. cit., 334 .

I: See discussion in Seligman, op. cit., supra, 517 ff., of 9 Am. Econ. Rev.; Lutz, The Progress of State Income Taxation since I9Ir (1920) Io ibid., 66, 77; Montgomery, Income Tax Procedure (x920) $335 \mathrm{ff}$., ibid. (I9I8) $77 \mathrm{ff}$. In England such gains have not been taxed except where the sales constituted 
view of Justice Pitney in the principal case. ${ }^{18}$ The point, however, is unfortunately not beyond dispute. The argument to the contrary is that as unrealized capital gains are capital so the sale of capital even though at a profit is only a change of form of capital. In Gray $v$. Darlington, ${ }^{19}$ which held that the act of 1867 did not tax gains on sales of bonds held for four years, it was stated that such gains are capital and not income. In cases under the corporation tax act of Igog it was held that the profits from sales might be included in computing the tax, ${ }^{20}$ but it has also been held that this is an excise or franchise and not an income tax and hence nice questions as to income were avoided. ${ }^{21}$ The language of Gray $v$. Darlington, seems to have been more or less approved in one case under the I913 act. $^{22}$ On principle is it not fairer to consider even appreciation of the value of capital as more nearly income, though too indefinite to be computed, than capital? Income which is not consumed by the owner becomes capital and capital can really be increased only by the addition of income. Such income added to capital may properly be taxed as income once either before or after it is added to capital. This is simply levying the tax

a part of the seller's business as a trader. Tebrau Rubber Syndicate (rgro) Scot. Cas. 906, 47 Scot. L. Rep. 816; Montgomery, op. cit.; though the situation is partly changed by a land increment value tax. Finance Act, rgIo; ro Edw. VII, ch. 8, pt. r. In Wisconsin, a statute taxing such gains has been held unconstitutional. State ex rel. Bundy v. Nygaard (I916) 163 Wis. 307, 158 N. W. 87, L. R. A. IgI7 E 563, note. Tax Com'r v. Putnam, supra, is contra. See also Park's Estate (I896) I73 Pa. I90, 33 Atl. 884; Miller v. Douglass (1875) 42 Tex. 288. In England a royal commission has urged further taxation of capital gains. The Manchester Guardian (weekly ed.) April 2, rgzo.

${ }^{18}$ "Income may be defined as the gain derived from capital, from labor, or from both combined; provided it be understood to include profit gained through a sale or conversion of capital assets, to which it was applied in the Doyle case" (see note 20, infra). "It is said that a stockholder may sell the new shares acquired in the stock dividend; and so he may, if he can find a buyer. It is equally true that if he does sell, and in doing so realizes a profit, such profit, like any other, is income, and so far as it may have arisen since the Sixteenth Amendment is taxable by Congress without apportionment." 40 Sup. Ct. I93, 195.

${ }^{10}$ (1872, U. S.) 15 Wall. 63. Here all that was necessary for a decision was the construction of the act, and any discussion as to the nature of capital gains was unnecessary.

${ }^{20}$ Doyle v. Mitchell Bros. Co: (1918) 247 U. S. 179, 38 Sup. Ct. 467; Hays v. Gauley Mountain Coal Co. (I9I8) 247 U. S. 189, 38 Sup. Ct. 470 , which treats Gray v. Darlington as a case merely of construction.

${ }^{21}$ Stratton's Independence v. Howbert (r913) 23I U. S. 399, 34 Sup. Ct. 136; Anderson v. Forty-Two Broadway Co. (I9I5) 239 U. S. 69, 36 Sup. Ct. I7.

${ }^{22}$ Lynch v. Turrish (1918) 247 U. S. 221, 230, 38 Sup. Ct. 537, which held merely that enhancement in value prior to the passage of the Amendment was not taxable, but which stated that Gray $v$. Darlington held an advance in value not to be income at all but merely increase of capital. See Lynch $v$. Turrish (1916, C. C. A. 8th) 236 Fed. 653, 660; Towne v. Eisner (19I7, S. D. N. Y.) 242 Fed. 702, 707; Holmes, Federal Taxes (I920) 63I-637. 
after the addition is made. The other argument proves too much, since if additions to capital by way of profits from sales are not income, no more should any additions to capital from current receipts be considered income. ${ }^{23}$ However this may be there is at most a division of opinion such that the judgment of Congress in this case should be considered not unreasonable.

The taxation of capital gains requires in justice ar allowance for capital losses, and this is provided for in the 1918 act. ${ }^{24}$ The result may operate to the detriment of the government since an incentive is given to the taxpayer to realize his losses while postponing the realization of gains. This might be viewed with equanimity in view of the expectation that actual capital gains will be realized and taxed ultimately, ${ }^{25}$ were it not for the presence of a large amount of tax exempt bonds, municipal, state and federal. The large investor will naturally put his money from investments sold at a loss into tax exempt securities, and hence there is a loss of this source of revenue to the Government for the future, accompanied by a present deduction from income for the year in which the change is made. Perhaps the most serious defect of our present system of income taxation is the existence of these securities, diverting capital from business needs and putting a premium on governmental extravagance. It would seem vitally necessary to find a way whereby all income is subject to the $\operatorname{tax}^{28}$

"seligman, op. cit., 525 of 9 AM. Econ. Rev.: "Capital is capitalized income."

${ }^{24}$ Act, Feb. 24, I9I9, sec. 214 a, 4, 5, 6. Such losses must be, in general, business losses and losses from transactions entered into for profit, as distinguished from losses in the nature of personal expenses. Montgomery, op. cit. (1920) 648-65x; Holmes, op. cit., 372.

${ }^{25}$ A question may arise whether under a progressive rate of taxation, such gains when realized should all be taxed within the year of realization, as in the I918 income tax act, or should be apportioned over a series of years: It has been urged that the time from which such gains are computed (now March I, I913, or approximately the date of adoption of the Sixteenth Amendment) should bo advanced from time to time. Lutz, op. cit.

${ }^{20}$ The unfortunate results of present conditions are graphically described by Kahn, Two Years of Faulty Taxation and the Results (1920) IX-12. They were accurately prophesied by Seligman, The Income Tax, supra, 615. It will be recalled that Governor Hughes asked the New York legislature to reject the Sixteenth Amendment on the ground that it permitted Congress to tax state and municipal bonds and thus vitally hamper state governments. It would seem that unfortunately Governor Hughes was probably wrong in his interpretation of the Amendment. See authorities collected in Ballantine, Some Constitutional Aspects of the Excess Profifs Tax (1920) 29 Y YLE LAW JouRNAL, 625, 629, 630, citing cases showing that such taxation was illegal before the Amendment, and that the Amendment did not grant any new power of taxation to Congress but simply removed a disability in taxing a certain kind of property. See also Eisner v. Macomber, supra. The economic arguments showing that such taxation would not hamper the governmental agencies of a state are set forth in Seligman, op. cit., 600-6I4. Possibly these argu- 
Other problems of an administrative nature will arise from an attempt to tax capital gains. Nevertheless these are not insurmountable and do not override the argument that failure to tax gains so made is unfair and unjust to those who are paying taxes on other forms of gain, such as salaries. ${ }^{27}$ Possibly as difficult a problem as any that may arise is how to tax such gains as between life-beneficiary and remainderman of a trust. Gains and losses upon conversion of capital units are held to affect the corpus of the estate, $i$. e., the interest of the remainderman, and only incidentally the interest of the life-tenant as the future yield from the corpus is thereby varied. ${ }^{28}$ Should the life-tenant in computing his taxable income deduct the losses or add the gains from changes in capital? It may seem anomalous at first, but it would appear that this is a case of unrealized loss or gain and should not affect the life-tenant's income. ${ }^{29}$

So another question of some interest may arise in connection with capital given away. Suppose A owns stock which doubles in value. He gives it to $B$ who sells at the increased value. Under present regulations the increase in value is not taxed. ${ }^{30}$

There is one other important constitutional point connected with Eisner v. Macomber, namely, may the "veil of the corporate entity" be pierced for the purposes of income taxation? The government in that case contended that the tax upon stock dividends might be con-

ments, coupled with the increasing tendency of the Court, following Veazie Bank v. Fenno (I870, U. S.) 8 Wall. 533, to uphold broadly grants of power to the federal government, even at the expenso of the states, may lead to a different result. See South Carolina v. United States (1905) x99 U. S. 437, 26 Sup. Ct. Ir, upholding a federal tax upon a state dispensary; First National Bank v. Union Trust Co. (1917) 244 U. S. 416, 37 Sup. Ct. 734, holding that, Congress having granted national banks in competition with state trust companies the power of acting as fiduciaries, such banks cannot be excluded from so acting by state legislatures; Seligman, op. cit., 615-621. Compare also Murdock v. Ward (1900) I78 U. S. 139, 20 Sup. Ct. 775; Whitney, op. cit., 286. The recent proposal of the Secretary of the Treasury quoted by Kahn, op. cit., 3, that the surtax rates upon taxable incomes be increased in proportion to the amount of income received by the taxpayer from tax-exempt securities, would, even if it is legal, be only partially helpful. $C f$. note $4 \mathrm{I}$, infra.

${ }^{\pi}$ See Lutz, op. cit., 77 of Ia AM. Econ. Rev.; Montgomery, op. cit. (1920) 334-34I; Seligman, 9 Am. Econ. Rev. 516; cf. Seligman, The Income Tax (2d ed. r9I4) 68I.

${ }^{24}$ Boardman v. Mansfield (xg07) 79 Conn. 634, 66 Atl. 169 ; Jordan v. Jordan (Ig06) 192 Mass. 337, 78 N. E. 459; Matter of Gerry (I886) 103 N. Y. 445. 9 N. E. 235; Neel's Estate (1904) 207 Pa. 446。 56 Atl. 950.

${ }^{\infty}$ This is the government's position. Treasury Decisions 2987, March I, 1920, adding Art. 347 to Regulatrons 45. If this is correct, the further position of the government that capital gains should be taxed to the fiduciary before being realized by the remainderman (ibid.) would seem questionable.

so Act, Feb. 24, 1919, sec. 202; Regulations 45, Art. 1562 ff. Should not such gain be held income to the donor? So there is no income on transmission of property by descent or devise. Regulations 45, Art. 343. Here inheritance taxes fill the gap to some extent. 
sidered as a tax upon the stockholder's share of the undivided profits held by the corporation. Justice Pitney stated that if the act were so construed it would be unconstitutional since undeclared dividends could not be considered income, and that a case deciding otherwise under the act of 1864 must be considered overruled. ${ }^{31}$ It would seem that the appropriate answer to the government's contention was that made by Justice Brandeis, dissenting, namely, that the act before the court (act of I9I6) would not bear such a construction. But Justice Pitney seems to assume that to hold a stock dividend to be capital is to foreclose the possibility of any income tax upon a stockholder's undivided interest in a corporation. It is submitted that such is not the case. An attempt to tax stock dividends as income when declared involves an admission of the existence of the corporate personality and a claimed detachment of property from that personality brought about by the simple declaration of the dividend. The situation is otherwise when the legislative body elects to adopt an entirely different theory of taxation and disregard entirely the corporate personality,a child of it or some other legislative body. Why may it not do so?

We are prone to forget what Professor Hohfeld so graphically portrayed, ${ }^{32}$ that a corporation is nothing more than one way in which individuals may carry on a business. Income in final analysis must be the amount of wealth flowing in during a given period "which is at the disposal of the owner for the purposes of consumption, so that in consuming it, his capital remains unimpaired." ${ }^{33}$ That is, it must be at the disposal of some one who may consume it if he chooses, thoughi actually he may not consume it but add it to his capital. This means that it must finally be at the disposal of some individual, since a corporation cannot consume wealth except as individuals are using the corporate form to produce further wealth. Surely the corporate frankenstein created by the individual is at bottom an aid to producing wealth, not a wealth-consumer, or it will not be employed. Hence to tax income in the hands of the corporation and again in the hands. of the stockholder is double taxation. ${ }^{34}$ Congress has made an attempt to avoid this by exempting cash dividends from the normal income tax but subjecting. such dividends to the surtaxes which are not

"Collector $v$. Hubbard (1870, U. S.) I2 Wall. I, holding that under the act of 1864 undivided profits of a corporation are taxable. Justice Pitney states that this case is overruled by Pollock v. Farmers Loan \& Trust Co. (1895) I58 U. S. 601, $627,628,637$, I5 Sup. Ct. 766 . But this seems to be true only to the extent that all previous income tax cases may be considered overruled by the Pollock case, which decided not of what income consisted but that an income tax was a direct tax. Collector v. Hubbard is discussed from the economic standpoint by Seligman, 9 AM. Econ. REv. 532, 533, supra.

"Hohfeld, Nature of Stockholders' Individual Liability for Corporation Debts (1909) 9 Col. L. REv. 285 ; cf. (I920) 29 Yale LAW Journal, 659.

"Seligman, The Income Tax (2d ed. Igr4) I9; 9 AM. Econ. REv. 523.

${ }^{3} C f$. (IgI8) 27 Yale Law JournaI, 682. 
levied upon corporations. Such attempt has now been largely abandoned since the excess profits tax is in effect a surtax levied upon corporations. Much of the current criticism of that tax is undoubtedly occasioned not so much by the tax itself, though it is unduly cumbersome in practice, as by the double taxation which it occasions. ${ }^{35}$ In addition, corporations must pay federal and state franchise or excise taxes, and possibly, as in Connecticut, a state income tax from which individuals are exempt. Or its stockholders may also be subject to state income taxes. The contrast between "industrious incomes" invested in corporations and "lazy incomes" invested in tax exempt bonds is striking and lends added force to the agitation for taxing "lazy incomes" at a higher rate as in England." Agitation for remedying the present system of income taxation has presupposed a fairer adjustment of individual and corporation taxes to avoid double taxation. $^{37}$ An interesting experiment in the way of avoiding double taxation has been the attempt in the 1918 act to assimilate personal service corporations-corporations whose gains depend upon the personal activities of its stockholders and not to any great extent upon invested capital-to partnerships by exempting such corporations from the corporation income tax and taxing the stockholders upon the income of the corporation. ${ }^{88}$ There has been so much administrative difficulty in working out normal and sur or graduated taxes between corporations and stockholders that this plan of disregarding the corporate entity entirely has seemed worthy of a fair trial. It may be that it would be the most feasible scheme for the taxation of all corporate incomes. Corporations might be required to file, as information at the source, returns showing their profits while the tax is levied only against the individual stockholders. Now it is obvious that unless we go too far in the other direction and unduly favor the corporate form of doing business undistributed profits must also be taxed. An individual is taxed both upon the income he consumes and upon the income he adds to capital, and hence the corporate income which is added to capital should also be taxed. Hence the experiment

\footnotetext{
${ }^{2}$ Haig, British Experience with Excess Profits Taxation (I920) Io AM. Econ. Rev. SuPP. I, p. I, pointing out that Great Britain is to retain the excess profits tax.

${ }^{30}$ Montgomery, op. cit. (1920) I7, I8 (1918) 18; Seligman, The Income Tax (2d ed. 1914) I99-200, 203, 204, 670, 702. Such distinction is made in the Massachusetts income tax (St. IgI6, ch. 269) and has been advocated by Herbert Hoover in the Saturdax Evening Post for April 10, I920.

${ }^{27}$ Dr. T. S. Adams, Immediate Future of the Excess Profits Tax (1920) Io Am. Econ. Rev. Supr. I, p. I5; cf. Seligman, The Next Step̣ in Tax Reform (1915) I9. Seligman there admits the ameliorating results from the tendency of the price of corporate securities to reflect such double taxation.

Act, Feb. 24, 19I9, sec. 200, 218 a. So by sec. 220 the profits of any corporation availed of for the purpose of preventing the imposition of the surtax upon its stockholders by accumulating profits, are taxed to the stockholders.
} 
can only be successful if all accumulated profits are taxed and this in turn requires that the corporate personality be disregarded. It is familiar law that the corporate personality may be disregarded under various circumstances, ${ }^{3 \theta}$ and on the other hand that partnerships are considered as entities for certain purposes, as under the bankruptcy act. ${ }^{40}$ It is, therefore, not a serious matter from a legal standpoint to disregard the personality created by law and hence it is regrettable that Justice Pitney has cast doubt upon this point, all the more as it was not necessary to his decision. His view leads to the question whether the creature of the legislature is more powerful than the legislature itself.

This does not mean that the legislature should be permitted at the same time to treat the corporation as a separate personality and also as a collection of individuals in order to increase taxable income. It may properly be required to take as to a particular corporation either one theory of taxation or the other. The dividing line between capital and income is elusive at best and the theory of the corporate entity should not be juggled to cover double taxation, even though such double taxation is permissible in itself.

Hence the decision in Eisner v. Macomber seems correct, but there are many important problems which it suggests but does not settle. It is most important that the taxability of realized capital gains as income be settled, and while there are administrative difficulties, the fairer plan seems to be that they should be taxed as income. It would seem also that the Sixteenth Amendment is broad enough to permit such taxation, and also that on general principles Congress as a legislative body may disregard the corporate entity for income taxing purposes. Nevertheless so long as there are available so many taxexempt securities, the income tax cannot be expected to operate with a high degree of fairness. ${ }^{41}$

${ }^{s 0}$ Authorities are cited by Justice Brandeis, dissenting. See also Comments (igr7) 27 Yale Law Journal, r08 and 248; (1920) 29 ibid., 659. See Comment, infra, p. 772 .

${ }^{*}$ Authorities cited by Justice Brandeis; cf. United States v. Coulby (19I8, N. D. Oh. E. D.) 25I Fed. 982, (r919, C. C. A. 6th) 258 Fed. 27.

Among law review comments and articles dealing with the income tax subjects herein treated, the following may be cited: on the nature of stock dividends, (I9I8) 3 I HARv. L. Rev. 787, (19I8) I8 Cor. L. Rev. 63, and an article in (19I8) I6 MICH. L. REv. 52I, arguing for the existence of the power in Congress to tax stock dividends which is denied by Eisner v. Macomber, supra; on the taxability of accumulated corporate earnings, (1918) I8 CoL. L. REv. 152, and (1918) I6 Mich. L. Rev. 232; and on the taxation of capital gains under the corporation act of I909, (I9I7) I7 CoL. L. REv. I49. In (I9I9) 32 Harv. L. REv. 926-928, Professor Powell argues strongly for the existence of the federal power to tax the income from state securities, relying in part upon P.eck \& Co.v. Lowe (Igr8) 247 U. S. I65, 38 Sup. Ct. 432, (IgI8) 27 Y YLE LAw JourNal, rog6, which held that a tax upon income from an exporting business was not a tax on exports within the constitutional prohibition. 